\section{OPEN JOURNAL SYSTEMS}

ISSN:2237-2202
Available on line at Directory of Open Access Journals

Journal of Hyperspectral Remote Sensing v.8, n.2 (2018) 85-94
Journal of Hyperspectral Remote Sensing

www.ufpe.br/jhrs

\title{
Soil physical characteristics near the reservoir of the Luiz Gonzaga hydroelectric power plant - PE
}

\author{
Yolly S. Ramos", Silvanete S. da Silva ${ }^{* *}$, Juarez P. Pedroza***, Antônio H. M. Fernández ${ }^{* * * *}$, Sallydelândia S. de \\ Farias \\ *PhD in Agricultural Engineering; Federal University of Campina Grande - UFCG, R. Aprígio Veloso, 882. Universitário, \\ Campina Grande - CG - Brasil. Email: yolyramos@gmail.com \\ ${ }^{* *}$ Graduate in Agricultural Engineering; UFCG. Email: silvanete.h@ hotmail.com (Corresponding author). \\ ${ }^{* * * *}$ Full professor of the UFCG. Email: juarez@ deag.ufcg.edu.br \\ ${ }^{* * * *}$ Geologist, Master; Federal University of Ceará - UFC, Department Environment San Francisco Hydroelectric Company \\ (CHESF), E-mail: helim@chesf.gov.br \\ Full professor of the UFCG. Email: farias@ deag.ufcg.edu.br
}

Received 10 August 2018; accepted 29 September 2018

\begin{abstract}
The erosive processes generated at the reservoir banks affect the quantity and the water supply, causing serious environmental and economic consequences. The objective of this study was to define the erosive laminar process in the surroundings of the reservoir of the Hydroelectric Power Plant. To perform the evaluation in sixteen areas, Echanced Thematic Mapper Plus images were used from Ladsat 7 satellite, RGB color composition and 543 bands, with nine classes of use and occupation of the areas, as well as the methodology with erosion pins. The pedological survey revealed a variation in the taxonomic classes, such as: Eutrophic Regolithic Neosol (area 1); Eutrophic Littoral Neosol (areas 2, 3, 4, 12 and 13); Optical Quartzene Neosol (areas 4, 6, 7, 8, 9, 10, 11 and 16); Luvissolo Crômico Órtico (area 5); And Eutrophic Haphol Plantain (area 15); The physical characterization of the soils and the soil loss of the marginal debulking (ranging from the very low to severe level) studied were susceptible to erosive processes. Soil loss in the studied areas varied from 85.00 to $205.20 \mathrm{~kg} \mathrm{ha}^{-1} \mathrm{ano}^{-1}$.

Keywords: physical degradation, sediments, soil loss.
\end{abstract}

\section{Introduction}

Desertification is a phenomenon of land degradation in arid, semi-arid and sub-humid dry areas, which are caused by several factors including climatic variation and human activities (kanna, 2014). This is a threat to the socio-economic conditions of millions of people living on dry land but representing a large area of land.

According to Kannan (2012), these processes are caused by complex interactions of various physical, biological, political, social, cultural and economic factors that hamper and gradually reduce the production capacity of the land over a long period.

The degree of degradation can be recognized through the state of the vegetation cover, because the vegetation interferes so much in the dynamics of water distribution. In the absence of vegetation cover, the soil can suffer erosive processes.
Erosion is a natural process of degradation, decomposition, transport and deposition of rock and soil materials and are classified by acting agents, and may be of wind, water or even glacial origin (Santos and Souza, 2016). Assim como a cobertura vegetal, o clima é outro fator que determina as diferenças entre o processo erosivo de uma região para outra, seja por meio do efeito direto das precipitações, seja pelo efeito indireto do estado da cobertura vegetal.

This statement highlights the importance of the presence of the vegetation cover on the soil surface, that there must be a degree of ground cover in order to control the impact of the water drops from the precipitations.

The elimination of the natural vegetation and the exploitation of the vegetation in the harvest, both deprotects the surface of the soil from the direct action of the rain and also causes the decrease of the organic matter (Santos and Souza, 2016). 
In the Brazilian Northeast, most of the activities are based on the exploitation of natural resources, and in particular the extraction of vegetation cover, the superpastejo of native areas and the agricultural exploitation by means of practices of soil management, often inadequate.

The predominant vegetation in this region is the Caatinga, which occupies an area of approximately $734,478 \mathrm{~km}^{2}$ (IBGE, 2010). This biome is exclusively Brazilian, which means that much of the biological heritage is not found anywhere else in the world (Silva et al., 2014).

Desertification nuclei have deforestation as the main activity that causes degradation. This is a consensual and justified indicator for the ease in observing changes, at both spatial and temporal scales, with the use of satellite images. However the works in the Northeast have considered the loss of vegetation cover as desertification only when the results are extensions of uncovered soil or with very sparse vegetation, without the presence of crops (Amaro et al., 2017).

There are in Brazil four large nuclei that find themselves with advanced degradation reaching the level of desertification. Are they: the Seridó region of Rio Grande do Norte and Paraíba, which present as degrading agents the deforestation of the Caatinga for the extraction of firewood and clay, the intensive use of natural resources and superpastejo; the nucleus of Irauçuba in Ceará is another region that is also heavily punished by deforestation, as well as the practice of burning and disordered land occupation; the nucleus of Gibués in Piauí, has been degraded by the mining and extensive livestock activities; and the Cabrobó nucleus in Pernambuco, which suffers from deforestation and salinization of the soil, as well as the superpastejo.

The most current mapping of vegetation and land cover mapping shows that the Caatinga Biome area still has $40.56 \%$ remaining native vegetation (IBGE, 2010). The rest of the ecosystem is compromised by some degradation process (Andrade and Romeiro, 2011). According to these authors, it is well known that the border region between Pernambuco, Ceará, Piauí and Bahia presents a large deforestation front, possibly related to the impact of the activities of the "Araripe Gentoo Pole".

The Araripe Pernambucano Region is an area where there is great pressure on natural resources, especially forest resources. The anthropic action is carried out with great intensity, resulting in areas degraded by the consumption of firewood to serve different economic sectors. This situation has demanded from the public power, the productive sector and the third sector, special attention to contain the pressure on the forest resources, as well as measures to avoid the process of environmental degradation. According to Carneiro et al. (2014), the use of the Caatinga is still based on purely extractive processes to obtain pastoral products, agriculture and timber merchant. These authors also point out that this predatory model is already felt mainly in the renewable natural resources of the caatinga, observing irrecoverable losses of floristic and faunistic diversity, accelerated erosion process and decline of soil fertility and water quality.

One of the techniques of remote sensing that is being developed to analyze changes in the environment using satellite imagery is Principal Component Analysis (PCA). This is a linear transformation technique that is used for different purposes: band enhancement and correlation, classifications, data compression, panchromatic band simulation, and change detection (Sá et al., 2011).

The analysis of the vegetation cover of the Araripe Pernambucano Region and the dynamics of the landscape are of extreme importance for the evaluation of the natural resources existing there, and the remote sensing becomes a very important tool in the quantification of these phenomena, since it can provide information of quickly and accurately. However, the objective of this work is to define the laminar erosive process around the reservoir of the Hydroelectric Plant.

\section{Materials and methods}

\section{Characterization of the study area}

This image analysis study was carried out between June 2013 and September 2015, in areas near the surroundings of the former Itaparica and now the Luiz Gonzaga Hydroelectric Power Plant located on the São Francisco River (Bahia and Pernambuco), 25 $\mathrm{km}$ downstream from the city of Petrolândia/PE.

The altitude of the basin in the region ranges from 200 to 800 meters and characterized by undulating topography $(8-20 \%)$, with very open valleys, frankly dissected relief with predominance of sandy cover. According to the climatic classification Köppen-Geiger (BSh) is hot and dry semiarid and, vegetation of the Caatinga. The average annual rainfall is $450 \mathrm{~mm}$, with rainy season, occurring in the months of February to May and with dry season in the months of June to January, and average annual temperature of $27^{\circ} \mathrm{C}$ (CHESF, 2013).

\section{Digital image processing}


The ETM - Echanced Thematic Mapper Plus images from the Ladsat 7 satellite were used for the analyzes and obtained in July 2001, with RGB color composition and 543 bands, with nine classes of use and occupation of the areas, they are: exposed soil; Water; the hyperxerophilic caatinga, antropizada, shallow shrub pattern, sparse pattern, dense pattern and arboreal pattern; agriculture and urban (CHESF, 2013).

The representations of the studied areas are in the land use and occupation map showing the vegetation classes and the collection points of the soil samples, generated with the aid of the software ENVI 3.5, through the parallelepiped (Jeasen, 1986).

The characterization of the vegetation present in the areas was determined as: hyperoxeropophilic caatinga and exposed soil (A1, A5, A6); only exposed soil (A3, A4, A8, A11 and A12); only hyperxerophilic caatinga (A7); (A9, A10, A13, A14, A15 and A16) and Caatinga standard arboreal (A2).
Sixteen (16) experimental and monitored areas were randomly selected and mapped to erosive techniques applied to the study, according to Figure 1.

The sediment samples from the bottom of the reservoir were collected at three points: P1, P2 and P3, located 10 (ten) meters from the extension of the eroded marginal area with four replicates. A dredger (Petite Ponar) was used, characterized by its disarming system (lever type) and capacity of collection of 4 liters. Afterwards, the samples were homogenized, packed in plastic bags, identified and sent for analysis in the laboratory AGROLAB - Environmental Analyzes.

The UTM coordinates of the sediment collection points were obtained using Global Positioning System (GPS) receiver equipment, model Garmim E-Trex Vista. A 40-HP Yamaha motorboat with a capacity of nine people was used to assist in the displacement of the soil and sediment samples inside the reservoir.
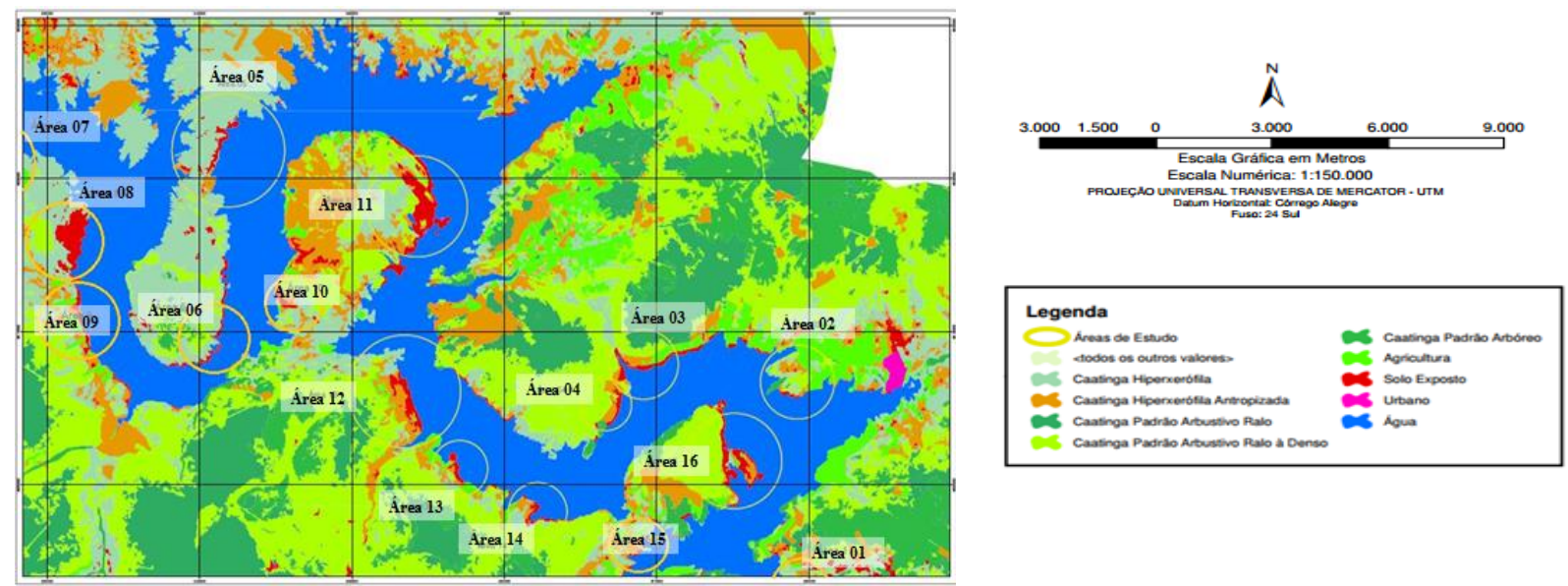

Figure 1 - Delimitation of the land use and occupation areas around the Luiz Gonzaga / PE hydroelectric power plant.

The physical characterization of the soil and sediments at the end of the reservoir resulted in the granulometric determination using the densimeter method, applying the sodium hexametaphosphate chemical dispersant recommended by Lemos and Santos (1996); and the soil density (DS) by the method of the test tube, according to EMBRAPA (2011).

The use of the "erosion pins" technique is commonly used, since it is a cheap and simple methodology. They are used to visually measure the occurrence of surface layer soil retraction in areas with erosive processes, as described by Guerra (2005), Morgan (2009) and Bertoni and Lombardi Neto (2014).
They are partially buried and the appearance of the graduated marks facilitates the reading and proves the erosive process (Scarpinella, 2012).

The pins were fixed around erosion areas. These erosion pins (identified) have dimensions of $4 \mathrm{x}$ $4 \times 40 \mathrm{~cm}$ and were installed $5 \mathrm{~cm}$ above the soil surface, far from human and animal interference, 10 meters away from the edge of the reservoir. The monitoring of the erosion pins was performed every 3 months, with measurements $(\mathrm{mm})$ under the pin exposure in relation to the soil, with a total of 8 replications, during 2 years. 
This methodology is used for the evaluation of surface soil retraction, as well as for monitoring the control lines in the experimental areas. The locating points of these pins were georeferenced and distanced from one another with variation depending on the size of the debarking (Table 1).

Table 1 - Specification of the UTM coordinates of the erosion pegs used in the experimental areas around the Luiz Gonzaga / PE hydroelectric plant

\begin{tabular}{|c|c|c|c|c|}
\hline \multirow{2}{*}{ Areas } & EPE & NPE & LRP & DSL \\
\hline & $\mathrm{M}$ & & UTM & $\%$ \\
\hline 1 & $20 \times 10$ & 24 & $\begin{array}{c}0579527-8992444 \\
0579508-8992418- \\
0579599-8992436- \\
0579554-8992408\end{array}$ & 6 \\
\hline 2 & $20 \times 10$ & 24 & $\begin{array}{l}0579115-9005926 \\
0579109-9005898 \\
0579156-9005916 \\
0579148-9005888\end{array}$ & 6 \\
\hline 3 & $20 \times 10$ & 21 & $\begin{array}{l}0571775-9008754 \\
0571725-9008724 \\
0571757-9008766 \\
0571714-9008742\end{array}$ & 5 \\
\hline 4 & $20 \times 30$ & 15 & $\begin{array}{l}0567713-9007456 \\
0567694-9007512 \\
0567749-9007472 \\
0567730-9007528\end{array}$ & 6 \\
\hline 5 & - & 1 & $0544527-0544527$ & 6 \\
\hline 6 & - & 1 & $0537486-9008090$ & 3 \\
\hline 7 & - & 1 & $0522024-9027734$ & 6 \\
\hline 8 & - & 1 & $0532433-9016485$ & 6 \\
\hline 9 & - & 1 & $0532709-9009641$ & 6 \\
\hline 10 & $20 \times 10$ & 15 & $\begin{array}{l}0545139-9010386 \\
0545130-9010324 \\
0545123-9010248 \\
0505113-9010336\end{array}$ & 6 \\
\hline 11 & - & 1 & $0554409-9016246$ & 8 \\
\hline 12 & $20 \times 10$ & 24 & $\begin{array}{l}0553485-9006592 \\
0553447-9006576 \\
0553500-9006614 \\
0553448-9006550\end{array}$ & 8 \\
\hline 13 & $20 \times 20$ & 24 & $\begin{array}{l}0557016-9000468 \\
0556999-9000446 \\
0557046-9000442 \\
0557035-9000426\end{array}$ & 6 \\
\hline 14 & $40 \times 50$ & 20 & $\begin{array}{l}0561003-8998852 \\
0560988-8998878 \\
0560976-8998830 \\
0560956-8998856\end{array}$ & 6 \\
\hline 15 & - & 1 & $0568521-8995076$ & 6 \\
\hline 16 & - & 1 & $0576098-9001709$ & 6 \\
\hline
\end{tabular}

Legend: $\mathrm{EPE}=$ spacing between erosion pins; $\mathrm{NPE}=$ number of erosion pins; LRP $=$ boundary of pinnets and DSL $=$ soil slope. 
The determination of soil loss caused by laminar erosion, according to equation 1 , suggested by Guerra (2005):

$$
\mathrm{PSE}=\mathrm{H}_{\mathrm{S}} \times \mathrm{EXT} \times \mathrm{D}_{\mathrm{a}} \quad \text { (Eq.1) }
$$

Where: PSE = estimation of soil loss with laminar erosion; $\mathrm{HS}=$ is the average exposure height of the pins $(\mathrm{m})$; EXT $=$ is the monitored area $\left(\mathrm{m}^{2}\right)$; and $\mathrm{Da}=$ is the apparent bulk density $\left(\mathrm{kg} / \mathrm{m}^{3}\right)$.

Then, the soil loss was calculated by marginal debarking, according to equation 2 :

$$
\mathrm{PSD}=\mathrm{HB} \times \mathrm{EXT} \times \mathrm{D}_{\mathrm{a}} \quad \text { (Eq.2) }
$$

Where: PSD $=$ refers to the soil loss factor through the marginal debarking; and $\mathrm{HB}=$ is the average height of the ravine (m).

As for the average height of the ravine, the planialtimetric survey was carried out along the edges of the experienced areas with positioning technique Real Time Kinematic = RTK, using the aid of the receiver GPS TOPCON TPS GR3 (with frequencies L1 e L2). In this way, the positioning data of the top of the ravine, in front of each of them, were recorded with the aid of the debulking monitoring pin.

Aiming to evaluate the classification of the results obtained from soil loss through laminar erosion and soil loss through the marginal debarking with susceptibility to erosion, the classification proposed by (Pereira, 2006).

The soils were classified according to the Normative Procedures of Pedological Surveys (EMBRAPA, 2011) and the identification of soil classes was based on the Brazilian Soil Classification System, SiBCS, (EMBRAPA, 2006), until the third grade categorical. Trenches have been opened (T1 a T16), one in each experimental area, totaling 16 (sixteen).

The soil map was elaborated by the computer program SURFER 10 (GOLDEN SOFTWARE INC, 2011). The shapes of the area were provided by the São Francisco Hydroelectric Company - CHESF, then imported into the desktop and consequently plotting. In this stage, all the editorial manipulations of the map that included the change of levels, the color filters and the contours, insertion of the color scales, magnetic north and texts, among others, were performed, listing the graphic types existing in the map of the area. In order to combine the maps, it was necessary to apply the Overlay technique to the manipulated shapes.

The descriptive statistics were analyzed by the Pearson correlation coefficient and the Scatterplots matrix with a significance level of 0.05 (probability of error of 5\%). For the analysis of the results, calculation spreadsheets were used in Microsoft Office Excel 2013 to obtain the graphs.

\section{Results and discussion}

The Table 2 shows the data of the average height of soil eroded, height of the exposure of the erosion pegs, extent of the monitored area and the average apparent density of the soil necessary for the estimation of the soil loss calculation in the period of two years, in the areas surrounding the Hydroelectric Power Plant.

It is observed that the average values of the apparent density varied between 1.50 and $1.73 \mathrm{~kg} \mathrm{~m}^{-3}$, conferring favorable conditions for the root development of cultures to be installed in the place. Soil losses were not higher due to the slope of the areas presenting flat relief in area 6 and soft to undulating in the other areas of the study. These lower losses may be associated with soil mineralogy and vegetation cover, which end up creating an uneven surface, reducing the velocity of the runoff and the transport of soil.

For the laminar erosion of the soils of the studied areas, classes and levels of erosion were verified, according to Pereira (2006). Class 1 and very low level ( $<6$ t ha- 1 year-1) were considered for all areas; except for 5, 6 and 11, in which the exposure height of the erosion pins was zero. Probably, the very low loss is influenced by the smooth to wavy relief in $95 \%$ of the studied areas (Lopes et al., 2015). 
Table 2 - Estimation of soil loss by laminar erosion in the areas surrounding the Luiz Gonzaga Hydroelectric Power Plant - PE for two years.

\begin{tabular}{lllll}
\hline \multirow{2}{*}{ Areas } & HS & EXT & DA & PSE \\
\cline { 2 - 5 } & $\mathrm{M}$ & $\mathrm{m}^{2}$ & $\mathrm{Kg} \mathrm{m}^{-3}$ & $\mathrm{Kg} \mathrm{ha}^{-1} \mathrm{year}^{-1}$ \\
\hline 1 & 0.010 & & 1.70 & 85.00 \\
3 & 0.018 & & 1.64 & 147.60 \\
4 & 0.012 & & 1.71 & 205.20 \\
5 & 0.014 & & 1.70 & 102.60 \\
6 & 0 & & - & - \\
7 & 0 & & - & - \\
8 & 0.012 & 1.50 & 90.00 \\
9 & 0.014 & $10,000 \mathrm{~m}^{2}$ & 1.51 & 105.70 \\
10 & 0.013 & & 1.52 & 98.80 \\
11 & 0.014 & & 1.63 & 114.10 \\
12 & 0 & & - & - \\
13 & 0.020 & & 1.73 & 173.00 \\
14 & 0.016 & & 1.69 & 135.20 \\
15 & 0.009 & & 1.66 & 74.70 \\
16 & 0.017 & & 1.66 & 141.10 \\
\hline
\end{tabular}

Legend: HS = exposure height of erosion pins; EXT = extension area monitored; DA = mean nt density of soil and PSE = soil loss.

In Table 3 are the quarterly data of the average height of the ravine, the extent of the monitored area and the apparent density of the soil. They were necessary for the estimation of the calculation of the soil loss through the marginal deburring in the areas around the plant, in the period of two years.

The comparison parameter for the soil losses through the marginal debarking of the studied areas was to the classes and erosion levels, according Pereira (2006). Class 1 and very low level $\left(<6 \mathrm{t} \mathrm{ha}^{-1} \mathrm{year}^{-1}\right)$ were considered for areas 2, 5, 8, 13, 15 and 16; class 2 and the low level (6 to $11 \mathrm{t} \mathrm{ha}^{-1}$ year $^{-1}$ ) for areas 4,9 and 12; class 3 and moderate level (11 to $22 \mathrm{t} \mathrm{ha}^{-1}$ year ${ }^{1}$ ) for areas 6 and 7; class 4 and high level (22 to 33 t ha $^{-1}$ year $^{-1}$ ) for area 3 ; and class 5 and severe level (> $33 \mathrm{t} \mathrm{ha}^{-1}$ year $^{-1}$ ) for area 11. For areas 1, 10 and 14, the mean height of the ravines was considered null. Although for the study region there are no studies reporting tolerance limits for soil loss, in comparison with literature, these losses, which varied from 85.00 to $205.20 \mathrm{~kg}$ ha-1 year -1, appear to be close of soil loss tolerance limits. Bertoni and Lombardi Neto (2014) showed that soil loss tolerance ranges from 1.9 to $7.3 \mathrm{t}$ $\mathrm{ha}^{-1}$ year $^{-1}$ for the so-called Litossolo soil and from 9.7 to $16.5 \mathrm{t}$ for some poorly developed soils in the state of São Paulo 1 year $^{-1}$ for the Regolossus, with a weighted average in relation to the depth of, respectively, 4.2 and $14.0 \mathrm{t} \mathrm{ha}^{-1}$ year $^{-1}$. Oliveira et al. (2008) verified that the tolerance of soil losses by erosion is around 5 $\mathrm{mg} / \mathrm{ha} /$ year for Neosolos of the state of Paraíba, while Silva et al. (2005) cite tolerance limits of 12.70 and $5.60 \mathrm{mg} \mathrm{ha}^{-1}$ year $^{-1}$ per year for, respectively, Latossolo and Cambissolo types of Lavras/MG.

Bertol and Almeida (2000) emphasize that it is essential to know the limits of tolerable soil loss to compare the relative efficiency of water erosion control of soil management systems. Evaluating methods of estimating losses tolerance for different soils of Santa Catarina, the authors found values ranging from 14.5 and $1.88 \mathrm{mg} \mathrm{ha}^{-1}$ year $^{-1}$ respectively for the Terra Bruna Structured soil and Litolics soils, considering a density of $1.25 \mathrm{mg} \mathrm{ha}^{-1}$ year $^{-1}$. 
Table 3 - Estimation of soil loss through marginal deforestation in the areas around the Luiz Gonzaga Hydroelectric Power Plant - PE, in the two year period.

\begin{tabular}{lllll}
\hline \multirow{2}{*}{ Areas } & HB & $\begin{array}{l}\text { EXT } \\
(\mathbf{H B} \mathbf{x} \mathbf{1 0 0 0})\end{array}$ & $\mathbf{D A}$ & PSD \\
\cline { 2 - 5 } & $\mathrm{M}$ & $\mathrm{m}^{2}$ & $\mathrm{Kg} \mathrm{m}^{-3}$ & $\mathrm{Kg} \mathrm{ha}^{-1} \mathrm{year}^{-1}$ \\
\hline 1 & - & - & - & - \\
2 & 1.83 & 1,830 & 1.64 & $30,012.00$ \\
3 & 10.00 & 10,000 & 1.71 & $256,500.00$ \\
4 & 6.6 & 6,480 & 1.70 & $82,365.00$ \\
5 & 0.44 & 440 & 1.42 & $3,124.00$ \\
6 & 2.43 & 2,430 & 1.60 & $155,520.00$ \\
7 & 4.34 & 4,340 & 1.50 & $195,300.00$ \\
8 & 0.66 & 660 & 1.51 & $24,915.00$ \\
9 & 1.39 & 1,390 & 1.52 & $63,384.00$ \\
10 & - & - & - & $384,100.00$ \\
11 & 4.60 & 4,600 & 1.67 & $85,635.00$ \\
12 & 3.30 & 3,300 & 1.73 & $7,436.00$ \\
13 & 0.88 & 880 & 1.69 & - \\
14 & - & - & - & $3,320.00$ \\
15 & 0.40 & 400 & 1.66 & $48,960.00$ \\
16 & 2.04 & 2,040 & 1.60 & $\mathrm{C}$ \\
\hline
\end{tabular}

Legend: $\mathrm{HB}=$ average height of the ravine; $\mathrm{EXT}=$ extension of the monitored area; DA = mean apparent density of $\mathrm{d}$ PSD $=$ soil loss of marginal debris.

The granulometric composition of the soil samples from the marginal debarking of the studied areas and sediments of the reservoir of the Luiz Gonzaga Hydroelectric Power Plant during the 2-year period is shown in Table 4. It is verified that the granulometric composition of the soil samples of the marginal debris showed higher amounts of AG $840.00 \mathrm{~g} . \mathrm{cm}^{-3}$ for area 3; AF $565.00 \mathrm{~g}$ $\mathrm{cm}-3$ to area 9 , from $\mathrm{S} 146.00 \mathrm{~g} \mathrm{~cm}^{-3}$ to area 5 and from ARG $228.00 \mathrm{~g} \mathrm{~cm}^{-3}$ to area 6.

Soils of marginal landslide have AG percentages higher than $35 \%$, which favors the margins a susceptibility to erosion, especially in the Neosols. The instability of the margin associated to the absence of ciliary vegetation contributes to the contribution of sediment in the reservoir of the plant. The textural class of the soil samples of the marginal landslide presented sand texture in the areas $1,2,3,4,7,8,9,11,12,13$, 14 and 16; with more than $90 \%$ sand, and clay and silt with less than $6 \%$ and $4 \%$, respectively.

In areas 5, 6, 10 and 15, they presented a sandy loam texture with more than $63 \%$ sand, and clay and silt with less than $22 \%$ and $15 \%$, respectively (Table 3).

The granulometric composition of the sediment samples from the reservoir presented a larger amount AG 833.00 g.cm-3 for area 2; AF $493.00 \mathrm{~g} \mathrm{~cm}-$ 3 for area 8, from $S 183.00 \mathrm{~g} \mathrm{~cm}-3$ for area 5 and ARG $247.00 \mathrm{~g} \mathrm{~cm}-3$ for area 5.

The textural class of the sediment samples from the reservoir showed sand texture in areas 1,2, 3, $4,7,8,9,11,12,13,14$ and 16; with more than $90 \%$ sand, and clay and silt with less than $6 \%$ and $4 \%$, respectively, according to Table 3 . In areas 5, 6, 10 and 15 they presented a sandy loam texture, with more than $63 \%$ sand, and clay and silt with less than $22 \%$ and $15 \%$, respectively. The deposited sediment presents the same textural composition of the soil of the marginal debarking of the studied areas, evidencing that the soil is being transported to the reservoir. 
Table 4 - Mean values of the physical characterization of soil and sediments in the studied areas of the Luiz Gonzaga / PE Hydroelectric Power Plant during the two year period.

\begin{tabular}{|c|c|c|c|c|c|c|c|c|c|c|}
\hline \multirow{3}{*}{ Areas } & \multicolumn{5}{|c|}{ Soils of marginal landslide } & \multicolumn{5}{|c|}{ Sediments } \\
\hline & AG & $\mathbf{A F}$ & $\mathbf{S}$ & ARG & $\begin{array}{l}\text { Textural } \\
\text { Class }\end{array}$ & AG & $\mathbf{A F}$ & $\mathbf{S}$ & ARG & $\begin{array}{l}\text { Textural } \\
\text { Class }\end{array}$ \\
\hline & \multicolumn{3}{|c|}{ g.cm ${ }^{-3}$} & \multicolumn{7}{|c|}{ g.cm ${ }^{-3}$} \\
\hline 1 & 786 & 158 & 16 & 40 & Sand & 639 & 280 & 55 & 26 & Sand \\
\hline 2 & 648 & 284 & 24 & 20 & Sand & 833 & 127 & 20 & 20 & Sand \\
\hline 3 & 840 & 118 & 0 & 40 & Sand & 694 & 266 & 20 & 20 & Sand \\
\hline 4 & 570 & 361 & 49 & 20 & Sand & 685 & 277 & 18 & 20 & Sand \\
\hline 5 & 404 & 246 & 146 & 224 & Franc Sandy & 325 & 245 & 183 & 247 & Franc Sandy \\
\hline 6 & 380 & 232 & 140 & 228 & Sandy franc & 509 & 251 & 140 & 100 & Sandy franc \\
\hline 7 & 450 & 488 & 8 & 54 & Sand & 489 & 471 & 20 & 20 & Sand \\
\hline 8 & 550 & 375 & 30 & 45 & Sand & 467 & 493 & 20 & 20 & Sand \\
\hline 9 & 359 & 565 & 34 & 42 & Sand & 723 & 230 & 21 & 26 & Sand \\
\hline 10 & 538 & 280 & 38 & 144 & Sand Franc & 388 & 356 & 176 & 80 & Sand Franc \\
\hline 11 & 430 & 488 & 18 & 64 & Sand & 468 & 492 & 20 & 20 & Sand \\
\hline 12 & 600 & 360 & 20 & 20 & Sand & 689 & 271 & 20 & 20 & Sand \\
\hline 13 & 617 & 323 & 40 & 20 & Sand & 687 & 244 & 42 & 27 & Sand \\
\hline 14 & 777 & 154 & 29 & 40 & Sand & 689 & 255 & 36 & 20 & Sand \\
\hline 15 & 530 & 162 & 108 & 200 & Sand Franc & 552 & 193 & 135 & 120 & Sand Franc \\
\hline 16 & 465 & 425 & 48 & 62 & Sand & 634 & 324 & 22 & 20 & Sand \\
\hline
\end{tabular}

Legend: $\mathrm{AG}=$ coarse sand, $\mathrm{AF}=$ fine sand, $\mathrm{S}=$ silt and $\mathrm{ARG}=$ clay.

Evaluating the Scatterplots matrix of the physical parameters of the soil samples of the marginal debarking with the sediments of the reservoir of the plant, there are common behaviors between the variables $\mathrm{AG}$ and $\mathrm{AF}$; and $\mathrm{S}$ and $\mathrm{ARG}$ (Figures $2 \mathrm{~A}$ and 2B). The AG correlated negatively with FA and presented a negative linearity, both in the physical parameters of the soil samples of the marginal debarking and the sediments $(\mathrm{r}=-0.63 \mathrm{p}<0.05)$ and $(\mathrm{r}$ $=-0.65, p<0.05)$, respectively. For higher values of AG, lower values of FA were found. Williams et al. (1976) and Silva (2012) verified that the sand negatively correlated with all the physical parameters (coarse sand, fine sand, silt and clay) of the sediments in the studied reservoirs.

The S correlated positively with ARG, both in the physical parameters of the soil samples of the marginal debarking as well as the sediments $(r=0.89$, $\mathrm{p}<0.05)$ e $(\mathrm{r}=0.99, \mathrm{p}<0.05)$, respectively. The deposition of fine or cohesive sediments such as silt and clay (with smaller diameter than $<0.65 \mathrm{~mm}$ ), in the collected points, occurs due to the low speed of the reservoir waters, corroborating with Santos (2015).

Williams (1976) and Silva (2015) verified that the sand correlated negatively with all the physical parameters of the studied sediments.

The sediments, once present in the aquatic ecosystem, have an important role for biota through the supply of nutrients and energy. In addition, sediment fulfills the function of regulating water quality by its ability to retain and release pollutants (Golterman et al., 1983). In addition, sediment fulfills the function of regulating water quality by its ability to retain and release pollutants.

Besides acting as carriers of other pollutants and cause abrasion in electromechanical equipment and hydraulic structures, second Carvalho (2008). 
Figure 2 - Matrix of Scatterplots for the variables: soil physics (A); sediments (B) from the deforestation of the Luiz Gonzaga/PE hydroelectric plant.

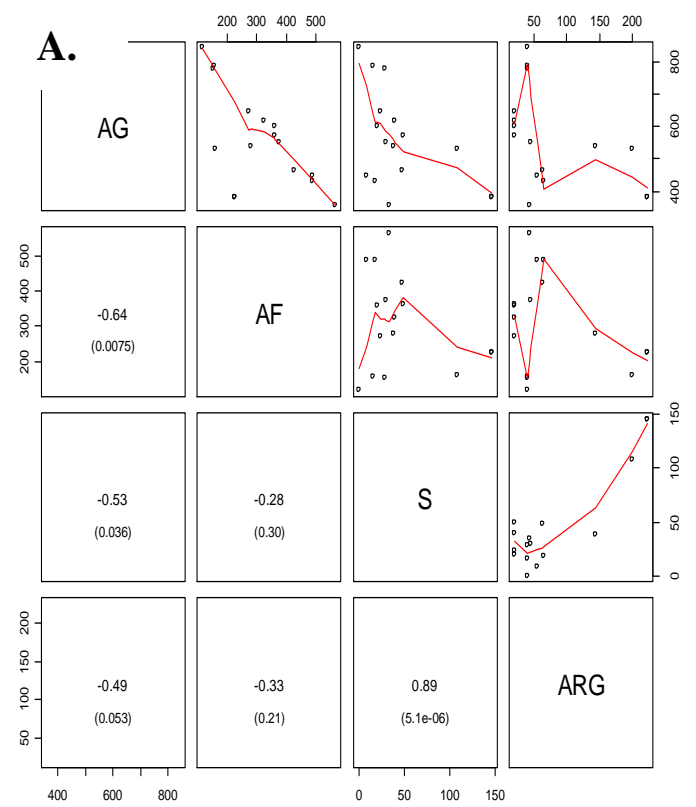

\section{Conclusions}

Soils in the areas surrounding the reservoir of the Luiz Gonzaga hydroelectric power plant were classified as Neosol Regolítico Eutrófico (RRe), in area 1; Eutrophic Littoral Neosol (RLe), in the areas 2, 3, 12, 13 e 4; Optical Quartzenetic Neosol (RQo), in the areas 4, 6, 7, 8, 9, 10, 11 e 16; Luvissolo Crômico Órtico (TCo), in the áreas 5 and Hapless Eucalyptus Planus (SXe), in the area 15.

The studied soils print physical attributes that make them fragile environmental units, especially regarding the susceptibility to laminar erosive processes and show that the most appropriate management is their effective conservation, with conservation and edaphic practices, with the aim of increasing the vegetation cover in the sandy texture alone;

Soil loss in the studied areas ranged from 85.00 to $205.20 \mathrm{~kg}$ ha-1 year-1, being close to tolerance limits in the literature;

Soil loss from the marginal landslide around the reservoir ranged from very low $\left(<6 \mathrm{t} \mathrm{ha}^{-1}\right.$ year $\left.^{-1}\right)$ to severe $\left(>33 \mathrm{t} \mathrm{ha}^{-1}\right.$ year $\left.^{-1}\right)$.

\section{Acknowledgments}

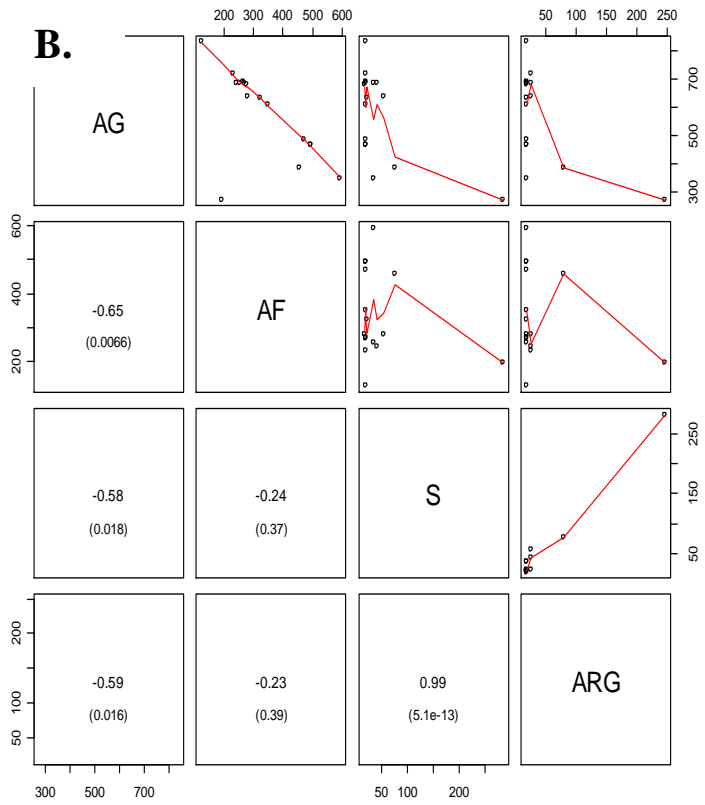

The authors of this paper thank the CNPq for granting the scholarship of the first author and the São Francisco Hydroelectric Company for the material support to carry out this study.

\section{References}

Amaro, G.E.deO., Galvão, M.L.deM., Maracajá, K.F.B., 2017. O processo de desertificação no município de Acari/RN e as alternativas de permanência para seus munícipes. Qualitas Revista Eletrônica 18, 83-97.

Andrade, D.C., Romeiro, A.R., 2011. Degradação ambiental e teoria econômica: Algumas Reflexões sobre uma "Economia dos Ecossistemas". Economia 12, 3-26.

Bertoni, J., Lombardi Neto, F., 2014. Conservação do Solo. 9. ed. Ícone, São Paulo.

Bertol, I., Almeida, J.A., 2000. Tolerância de perda de solo por erosão para os principais solos do estado de Santa Catarina. Revista Brasileira de Ciência do Solo 24, 657-668.

Carvalho, N.O., 2008. Assoreamento de reservatórios: consequências e mitigação dos efeitos. Encontro Nacional de Engenharia de Sedimentos, Santa Maria.

Carneiro, V.A., Paulo, P.O., Melo, E.M.L., 2014. 
Paisagens degradadas do município de Palmelo (Goiás): o estudo das voçorocas via trabalho de campo. GeoTextos 10, 179-207.

CHESF. Companhia Hidroelétrica do São Francisco, 2013. Departamento de meio ambiente. Mapeamento e monitoramento dos processos erosivos nas encostas da Usina Hidrelétrica de Itaparica. CHESF, Recife.

EMBRAPA. Empresa Brasileira de Pesquisa Agropecuária, 2011. Centro Nacional de Pesquisas de Solos. Manual de Métodos de Análises de Solos. 2. ed. Embrapa Solos, Rio de Janeiro.

EMBRAPA. Empresa Brasileira de Pesquisa Agropecuária, 2006. Sistema Brasileiro de Classificação de Solos. 2. ed. Embrapa, Brasília.

GOLDEN SOFTWARE, 2011. Surfer 10 Quick Start Guide Contouring and 3D Surface Mappingfor Scientists and Engineers. Available: http://www.goldens oftware.com. Acess: $7 \mathrm{dec}$. 2015.

Golterman, H.L., Sly, P.G., Thomas, R.L., 1983. Study of the Relationships Between Water Quality and Sediment Transport. A Guide for the Collection and Interpretation of Sediment Quality Data. Unesco, Paris. (Technical Papers in Hydrology, 26).

Guerra, A.J.T., 2005. Experimentos e monitoramentos em erosão dos solos. Revista do Departamento de Geografia 16, 32-37.

IBGE. Instituto Brasileiro de Geografia e Estatística, 2010. Mapa de biomas e de vegetação. Disponível: https://ww2.ibge.gov.br/home/presidencia/noticias/2 1052004 biomashtml.shtm.Acesso: 10 out. 2017.

Kannan, A., 2014. Challenges of compliance with multilateral environmental agreements: the case of the United Nations Convention to Combat Desertification in Africa. Journal of Sustainable Development Studies 5, 145-168.

Kannan, A., 2012. Global Environmental Governance and Desertification: a study of gulf cooperation council countries. The Concept Publishers, New Delhi.

Jensen, J.R., 1986. Introductory digital image processing: a remote sensing perspective. PrenticeHall, New Jersey.

Lemos, R.C., Santos, R.D., 1996. Manual de descrição e coleta de solo no campo. 3. ed. Sociedade Brasileira de Ciência do Solo/Embrapa - CNPS,
Campinas.

Lopes, J.W.B., Araújo Neto, J.R.De, Pinheiro, E.A.R., 2015. Produção de sedimentos e assoreamento em reservatório no semiárido: o caso do açude Marengo, Ceará. Revista Eletrônica do Curso de Geografia 24, 16-31.

Morgan, R.P.C., 2009. Soil Erosion and Conservation. Blackwell Science, Australia.

Oliveira, F.P. Santos, D., Silva, I.F., Silva, M.L.N., 2008. Tolerância de perda de solo por erosão para o estado da Paraíba. Revista de Biologia e Ciências da Terra 8, 60-71.

Pereira, A.R., 2006. Determinação da perda de solo. FAPI, Belo Horizonte. (Boletim técnico, 001).

Sá, I.I.S., Galvíncio, J.D., Moura, M.S.B.de., Sá, I.B., 2011. Avaliação da degradação ambiental na região do Araripe Pernambucano utilizando técnicas de sensoriamento remoto. Revista Brasileira de Geografia Física 6, 1292-1314.

Santos, W.A.A.dos, Souza, H.C.de, 2016. Atuação, monitoramento e análise de processos erosivos no âmbito de parques eólicos: estudo de caso nas regiões litorâneas e agreste do Nordeste brasileiro. Revista de Geociências do Nordeste 2, 133-142.

Santos, B.S., 2015. Estudo da concentração de sedimentos em suspensão no reservatório de MogiGuaçi (SP). Dissertação (Mestrado). São Carlos, USP.

Scarpinella, G.A.de, 2012. Erosão em carreadores da cultura da cana-de-açúcar: estudo de caso na bacia do Ribeirão do Feijão (SP). Tese (Doutorado). São Carlos, USP.

Silva, N.da, Lucena, R.F.P.de, Lima, J.R.deF., Lima, G.D.S., Carvalho, T.K.N., Sousa Junior, S.P.de, Alves, C.A.B., 2014. Conhecimento e uso da vegetação nativa da Caatinga em uma comunidade rural da Paraíba, nordeste do Brasil. Boletim do Museu de Biologia Mello Leitão 34, 5-37.

Silva, A.M., Silva, M.L.N, Curi, N., Lima, J.M.de, Avanzi, J.C., Ferreira, M.M., 2005. Perdas de solo, água, nutrientes e carbono orgânico em Cambissolo e Latossolo sob chuva natural. Pesquisa Agropecuária Brasileira 40, 1223-1230.

Williams, J.D.H., Jequer, J.M., Tsouas, R.L., 1976. Forms of phosphorus in the surficial sediments of Lake Erie. Journal of the Fisheries Research Board of Canada 33, 429-413. 